\title{
MANAJEMEN PEMBELAJARAN S1 KEPERAWATAN STIKES YOGYAKARTA
}

\author{
Teti Indriati Kastuti, Lantip Diat Prasojo \\ FIB Universitas Teknologi Yogyakarta, Universitas Negeri Yogyakarta \\ tetiindriati@yahoo.co.id, lantip1975@gmail.com
}

\begin{abstract}
Abstrak
Penelitian ini bertujuan untuk mendeskripsikan manajemen pembelajaran dilihat dari segi pe-rencanaan, pelaksanaan, dan evaluasi kurikulum di S1 Keperawatan STIKES Yogyakarta. Penelitian ini merupakan penelitian deskriptif dengan pendekatan kualitatif. Subjek penelitian adalah Pembantu Ketua I, III, dosen, kepala bagain akademik, perpustakaan, laboratorium, dan mahasiswa. Data peneli-tian dikumpulkan melalui wawancara, observasi, dan studi dokumentasi. Dianalisis secara kualitatif dengan menggunakan teknik analisis interaktif model Miles dan Huberman. Hasil penelitian bahwa perencanaan pembelajaran: 1) rumusan kompetensi pendukung dan lainnya tidak terjabarkan dalam elemen kompetensi; 2) proses pembelajaran memerlukan team teaching. Pelaksanaan pembelajaran: 1) pembinaan motivasi belajar mahasiswa masih ada dosen yang mengajar berdasarkan mood; 2) bahan ajar dimanfaatkan dengan baik untuk mencapai tujuan instruksional pembelajaran; 3) bimbing-an dan konseling pada saat pengisian KRS; 4) masih ada dosen yang mengganti jadwal. Evaluasi pembelajaran: 1) penamaan mata kuliah IKD 1 dan 2, yang menunjukkan prerequisite, kenyataannya tidak berhubungan; 2) evaluasi dosen sebatas pelaksanaan administratif.
\end{abstract}

Kata kunci: manajemen, kurikulum, pembelajaran, keperawatan

\section{THE MANAGEMENT OF THE S1 NURSING LEARNING OF STIKES YOGYAKARTA}

\author{
Teti Indriati Kastuti, Lantip Diat Prasojo \\ FIB Universitas Teknologi Yogyakarta, Universitas Negeri Yogyakarta \\ tetiindriati@yahoo.co.id, lantip1975@gmail.com
}

\begin{abstract}
This study aims to investigate the management of a learning in terms of planning, implementa-tion, and evaluation in the S1 nursing program in STIKES Yogyakarta.This was a descriptive study employing the qualitative approach. The research subjects were the Head, Head Assistants I and III, lecturers, personnel in the academic section, library, and laboratory, and students. The data were collected through interviews, observations, and document study and were qualitatively analyzed using the interactive analysis technique by Miles and Huberman. The results of the study are as follows. The learning planning, 1) the formulation of the supporting competencies and others is not elaborated in competency elements; 2) the learning process needs team teaching. Learning implementation, 1) in developing students' learning motivation, some lecturers teach on the basis of mood, lacking respect and self-control; 2) learning materials are well utilized to attain the learning instructional objectives; 3) guidance and counseling are limited to the completion of the study plan card and it is compulsory for students to join extracurricular activities and community services; and 4) in the classroom management in terms of time discipline, some lecturers often swap the schedule and are absent. The learning evaluation, 1) the names of the IKD subjects use numbers 1 and 2 showing a prerequisite but in practice they are not related; and 3) the evaluation of lecturers is still limited to administrative implementation.
\end{abstract}

Keywords: management, curriculum, instructions, nursing 


\section{Pendahuluan}

Kurikulum merupakan suatu sistem program pembelajaran untuk mencapai tujuan institusional pada lembaga pendidikan, sehingga kurikulum memegang peranan penting dalam mewujudkan sekolah yang bermutu. Perubahan sosial politik dan tatanan budaya di Indonesia akhirnya menuntut perubahan paradigma pendidikan nasional yang semula kebijakan pemerintah dilakukan secara sentralisasi telah berubah menjadi desentralisasi yang menekankan bahwa pengambilan kebijakan pendidikan dari pemerintah pusat (top government) ke pemerintah daerah (local government) yang berpusat di pemerintahan kota dan kabupaten. Menurut Kepmendiknas Nomor 232/U/2000 didefinisikan sebagai berikut "Kurikulum pendidikan tinggi adalah seperangkat rencana dan pengaturan mengenai isi maupun bahan kajian dan pelajaran serta cara penyampaian dan penilaian yang digunakan sebagai pedoman penyelenggaraan kegiatan belajar-mengajar di perguruan tinggi". UNESCO (1998) menjelaskan bahwa untuk melaksanakan empat perubahan besar di pendidikan tinggi tersebut, dipakai dua basis landasan berupa empat pilar pendidikan yaitu: 1) learning to know, 2) learning to do yang bermakna pada penguasaan kompetensi dari pada penguasaan keterampilan menurut klasifikasi ISCE (International Standard Classification of Education) dan ISCO (International Standard Classification of Occupation), dematerialisasi pekerjaan dan kemampuan berperan untuk menanggapi bangkitnya sektor layanan jasa, dan bekerja di kegiatan ekonomi informal, 3. learning to live together (with others), dan 4. learning to be, serta belajar sepanjang hayat (learning throughout life).

Dalam proses pendidikan perlu dilaksanakan manajemen kurikulum agar perencanaan, pelaksanaan, dan evaluasi kurikulum berjalan lebih efektif, efisien, dan optimal dalam memberdayakan berbagai sumber belajar, pengalaman belajar, maupun komponen kurikulum (Rusman, 2011, p.5). Untuk mengimplementasikan kurikulum diperlukan pengelolaan yang efektif dan efisien melalui pembelajaran. Berdasarkan hasil penilaian BAN-PT dengan jenjang terakreditasi $C$ dan hasil prapenelitian di S1 Keperawatan Sekolah Tinggi Ilmu Kesehatan (STIKES) Yogyakarta diperoleh informasi bahwa perencanaan kurikulum di S1 Keperawatan STIKES Yogyakarta yang mengacu kepada Kurikulum Berbasis Kompetensi (KBK) terdiri dari kurikulum inti dan institusional belum sepenuhnya dilaksanakan. Berdasarkan latar belakang di atas, maka penelitian tentang "Manajemen Pembelajaran di S1 Keperawatan STIKES Yogyakarta" penting dilakukan.

Identifikasi permasalahan yang berkaitan dengan manajemen pembelajaran di S1 Keperawatan STIKES Yogyakarta sebagai berikut: 1) kurikulum di S1 Keperawatan STIKES Yogyakarta belum dikembangkan dengan baik sesuai dengan standar pengelolaan Kurikulum Berbasis Kompetensi (KBK).; 2) terdapat dosen yang belum memenuhi standar pelaksanaan KBK.; 3) jadwal kuliah tidak konsisten, sering ada perubahan jadwal kuliah.; 4) Evaluasi terhadap pelaksanaan pembelajaran belum optimal. Dari identifikasi permasalahan, penelitian dapat difokuskan pada masalah manajemen pembelajaran yang meliputi perencanaan, pelaksanaan, dan evaluasi.

Tujuan penelitian adalah diharapkan dapat memberikan manfaat baik secara teoretis maupun praktik dalam kajian dan praktik manajemen pembelajaran.

Bagi sebuah organisasi, manajemen merupakan kunci sukses karena sangat menentukan kelancaran kinerja organisasi yang bersangkutan. Menurut Daft (1991, p.5), "Management is the attainment of organizational goals in an effective and efficient manner through planning, organizing, leading, and controlling organizational resources", yaitu manajemen adalah pencapaian tujuan organisasi secara efektif dan efisien melalui perencanaan, pengorganisasian, kepemimpinan, dan pengendalian sumber daya organisasi. Kurikulum dan pembelajaran sebagai salah satu ruang lingkup manajemen pendidikan perlu dikelola dengan efektif dan efisien untuk mencapai tujuan. 
Kurikulum lebih luas daripada sekedar rencana pelajaran, tetapi meliputi segala pengalaman atau proses belajar siswa yang direncanakan dan dilaksanakan di bawah bimbingan lembaga pendidikan. Oliva (1992, p.10) mengemukakan, "Curriculum as a program, a plan, content, and learning experiences which the learner encounters under the direction of the school", yang artinya kurikulum sebagai sebuah program, rencana, konten, dan pengalaman belajar yang para pembelajar temui di bawah arahan sekolah. Kurikulum merupakan program pembelajaran, sedangkan pembelajaran merupakan cara bagaimana mempersiapkan pengalaman belajar bagi peserta didik. Menurut Oemar Hamalik (2012, p.57), "Pembelajaran adalah suatu kombinasi yang tersusun meliputi unsurunsur manusiawi, material, fasilitas, perlengkapan, dan prosedur yang saling memengaruhi mencapai tujuan pembelajaran".

Hubungan lain antara kurikulum dengan pembelajaran dapat juga dilihat dari silabus dalam setiap mata pelajaran. Silabus ini biasanya disusun dalam satu semester dan terdiri atas berbagai komponen, antara lain: standar kompetensi, kompetensi dasar, tujuan pembelajaran, urutan topik-topik, skenario pembelajaran, pendekatan dan strategi, media dan sumber belajar serta sistem penilaian. Komponen tersebut memiliki kesamaan dengan komponen pembelajaran. Jika kurikulum adalah programnya, maka pembelajaran merupakan implementasinya. Jika kurikulum adalah konsepnya, maka pembelajaran adalah konsepnya. Jika kurikulum merupakan teorinya, maka pembelajaran praktiknya Apa yang dapat dilihat dan dilakukan dalam pembelajaran, itulah sesungguhnya kurikulum nyata (real curriculum).

Mengadapsi fungsi manajemen dari para ahli, fungsi manajemen yang sesuai de-ngan profil kinerja pendidikan secara umum adalah melaksanakan fungsi planning, organizing, staffing, coordinating, leading (facilitating, motivating, innovating), reporting, controlling (Tim Dosen AP UPI, 2011, p.92). Sistem pendidikan tinggi di- lihat sebagai sebuah proses akan memiliki empat tahapan pokok yaitu masukan (input), proses, luaran (output) dan hasil ikutan (outcomes). Untuk menghasilkan output dan outcomes yang dikehendaki, maka diperlukan pengelolaan pembelajaran yang terdiri dari perencanaan, pelaksanaan dan evaluasi. Menurut Tyler (Nasution, 1993, p.140), "Langkah-langkah dalam perencanaan kurikulum adalah: 1) menentukan tujuan pendidikan; 2) menentukan proses belajar mengajar; 3) menentukan organisasi kurikulum; 4) menentukan cara menilai hasil belajar". Kurikulum Pendidikan Tinggi berdasarkan SK Menteri Pendidikan Nasional Nomor 232 Tahun 2000 (Veithzal Rivai dan Sylviana Murni, 2012, p.178), "Berdasarkan pemikiran tentang tujuan belajar, maka matakuliah dalam kurikulum perguruan tinggi dibagi atas lima kelompok, yaitu: 1) Matakuliah Pengembangan Kepribadian (MPK), 2) Matakuliah Keilmuan dan Keterampilan (MKK), 3) Matakuliah Keahlian Berkarya (MKB), 4) Matakuliah Perilaku Berkarya (MPB), 5) Matakuliah Berkehidupan Bermasyarakat (MBB)".

Menentukan proses belajar menurut Rusman (2012, p.4) dijelaskan bahwa perencanaan proses pembelajaran meliputi Silabus dan Rencana Pelaksanaan Pembelajaran (RPP) yang memuat identitas mata pelajaran, Standar Kompetensi (SK), Kompetensi Dasar (KD), indikator pencapaian kompetensi, tujuan pembelajaran, materi ajar, alokasi waktu, metode pembelajaran, kegiatan pembelajaran, penilaian hasil belajar, dan sumber belajar.

Menurut TIM Dosen AP UNY (2010, p.43), "Tahap pelaksanaan kurikulum merupakan tahap pelaksanaan pembelajaran, sedangkan kegiatan manajemen kurikulum pada tahap ini berupa kegiatan pengelolaan pembelajaran, misalnya melalui manajemen kelas". Kualitas pembelajaran dapat dilihat dari segi proses dan dari segi hasil. Dari segi proses, pembelajaran dikatakan berhasil dan berkualitas apabila seluruhnya atau setidak-tidaknya sebagian besar peserta didik terlibat secara aktif, baik fisik, mental, maupun sosial dalam proses pem- 
belajaran, disamping menunjukkan kegairahan belajar yang tinggi, semangat belajar yang besar, dan rasa percaya pada diri sendiri. Sedangkan dari segi hasil, proses pembelajaran dikatakan berhasil apabila terjadi perubahan perilaku yang positif pada diri peserta didik seluruhnya atau setidak-tidaknya sebagian besar. Dapat disimpulkan bahwa pengelolaan pembelajaran adalah proses mengolah seluruh aktifitas dan seluruh unsur (manusia dan nonmanusia) agar tujuan instruksional/pembelajaran dapat tercapai secara efektif dan efisien.

Untuk mencapai tujuan pembelajaran diperlukan unsur-unsur pembelajaran. Menurut Oemar Hamalik (2012, p.66), “Unsurunsur minimal yang harus ada dalam sistem pembelajaran adalah seorang siswa/ peserta didik, suatu tujuan dan suatu prosedur kerja untuk mencapai tujuan". Unsur pembelajaran konkruen dengan unsur belajar. Menurut Oemar Hamalik (2012, p.50), "Unsur-unsur yang terkait dalam proses belajar terdiri dari: 1) motivasi siswa, 2) bahan belajar, 3) alat bantu belajar, 4) suasana belajar, 5) kondisi subjek yang belajar".

Suatu aktivitas belajar sangat lekat dengan motivasi. Perubahan suatu motivasi akan mengubah pola wujud, bentuk, dan hasil bela-jar. Ada tidaknya motivasi seorang individu untuk belajar sangat berpengaruh dalam proses aktivitas belajar itu sendiri. Thomas M.Risk (Ahmad Rohani, 2010, p.12) memberikan pengertian motivasi sebagai berikut, We may definen motivation, in a pedagogical sense, as the concious effort on the part of the teacher to establish in students motives leading to sustained activity toward the learning goals (Motivasi adalah usaha yang disadari oleh pihak guru untuk menimbulkan motif-motif pada diri peserta didik/ pelajar yang menunjang ke-giatan ke arah tujuan-tujuan belajar). Menjadi jelaslah bahwa salah satu masalah yang dihadapi guru untuk menyelenggarakan pengajaran adalah bagaimana memotivasi atau menumbuhkan motivasi dalam diri peserta didik secara efektif.

Menurut Alben Ambarita (2006, p.80), adapun sikap dan karakteristik guru yang sukses mengajar secara efektif dapat diidentifikasikan sebagai berikut:(1) respek dan memahami dirinya, serta dapat mengontrol dirinya (emosinya stabil); (2) antusias dan bergairah terhadap bahan, kelasnya, dan seluruh pengajarannya; (3) berbicara dengan jelas dan komunikatif; (4) memperhatikan perbedaan individual peserta didik; (5) memiliki banyak pengetahuan, inisiatif, kreatif, dan banyak akal; (6) menghindari sarkasme dan ejekan terhadap peserta didiknya; (7) tidak menonjolkan diri, dan (8) menjadi teladan bagi peserta didiknya.

Menurut Pearson dan Moomaw (İbrahim Hakkı Öztürk dalam Jurnal Curriculum Reform and Teacher Autonomy in Turkey: The Case of The History Teaching) mengungkapkan,

...recognizing teaching as a profession and developing professional teachers is a possible solution to teachers lack of motivation and satisfaction, professionalism, and empowerment, as well as teacher stress. If teachers are to be empowered and regarded as professionals, then, like other professionals, they must have the freedom to prescribe the best treatment for their students (as doctors and lawyers do for their patients and clients). Experts have defined that freedom as teacher autonomy.

...mengakui pengajaran sebagai suatu profesi dan mengembangkan guru profesional adalah solusi yang mungkin untuk guru yang kurang motivasi dan kepuasan, profesionalis-me, dan pemberdayaan, serta stres guru. Jika guru harus diberdayakan dan dianggap sebagai profesional maka seperti profesional lainnya mereka harus memiliki kebebasan untuk me-nentukan perlakuan terbaik bagi siswanya (seperti yang dilakukan dokter dan pengacara untuk pasien dan klien mereka). Para ahli mendefinisikan kebebasan sebagai otonomi guru.

Dalam desain pengajaran yang biasa disusun guru terdapat salah satu komponen pengajaran yang dirancang berupa sumber belajar/pengajaran yang umumnya diisi dengan buku-buku rujukan. Pengertian sumber belajar sesungguhnya 
tidak sesederhana itu. Menurut Ahmad Rohani (2010, p.185), bahwa segala daya yang dapat dipergunakan untuk kepentingan proses/aktivitas pengajaran baik secara langsung maupun tidak langsung, di luar dari peserta didik (lingkungan) yang melengkapi dari mereka pada saat pengajaran berlangsung disebut sebagai sumber belajar. Menurut Rusman (2011, p.138), klasifikasi jenis-jenis sumber belajar yaitu, (1) pesan/message, (2) manusia/ people, (3) bahan/material, (4) peralatan/ device, (5) teknik/metode, dan (6) lingkungan/setting.

Menurut Oemar Hamalik (2012, p.100), "Pendayagunaan lingkungan dalam proses pembelajaran dapat dilaksanakan dengan berbagai cara, yakni dengan membawa lingkungan ke dalam kelas, dan dengan cara membawa siswa ke masyarakat". Yang dimaksud dengan cara pertama yaitu berkenaan dengan manusia yakni sumber masyarakat atau orang tertentu dengan pengalaman dan kemampuan dalam suatu bidang tertentu diminta untuk memberikan bimbingan. Menurut Ahmad Rohani (2010, p.147), “Tindakan pengelolaan kelas adalah tindakan yang dilaku-kan oleh guru dalam rangka penyediaan kondisi yang optimal agar proses belajar mengajar berlangsung efektif". Tindakan guru tersebut dapat merupakan tindakan dalam mengatur lingkungan belajar, mengatur peralatan, dan lingkungan sosioemosional. Tindakan guru tersebut dapat merupakan tindakan dalam mengatur lingkungan belajar, mengatur peralatan, dan lingkungan sosio-emosional. 1) Kondisi fisik: ruangan tempat berlangsungnya proses belajar mengajar, pengaturan tempat duduk, ventilasi dan pengaturan cahaya, pengaturan penyimpanan barangbarang.; 2) Kondisi sosio-emosional: tipe kepemimpinan, sikap guru, suara guru, pembinaan raport.; 3) Kondisi organisasional: penggantian pelajaran dan kuliah, guru yang berhalangan hadir, ma-salah antar peserta didik.

Menurut Gerlack dan Ely (Alben Ambarita, 2006, p.70) "Ada dua jenis strategi pembelajaran, yaitu expository approach (pen-dekatan ekspositori) dan inquiry approach (pendekatan inkuiri)". Nana Sudjana (2011, p.76) menyatakan, "Metode mengajar ialah cara yang dipergunakan guru dalam mengadakan hubungan dengan siswa pada saat berlangsungnya pengajaran". Oleh karena itu peranan metode mengajar sebagai alat untuk menciptakan proses mengajar dan belajar. Dengan metode ini diharapkan tumbuh berbagai kegiatan belajar siswa sehubungan dengan kegiatan mengajar tenaga pendidik. Metode mengajar yang baik adalah metode yang dapat menumbuhkan kegiatan belajar siswa. Proses pembelajaran yang baik, hendaknya mempergunakan berbagai jenis metode mengajar secara bergantian atau saling bahu-membahu satu sama lain. Tu-gas tenaga pendidik ialah memilih berbagai metode yang tepat untuk menciptakan proses pembelajaran. Menurut Ahmad Rohani (2010, p.139), metode adalah suatu cara yang sistematik dan umum. Ia berfungsi sebagai alat untuk mencapai suatu tujuan. Ada banyak ragam metode pengajaran, diantaranya: metode ceramah, diskusi, tanya jawab, resitasi, drill, Struktural Analitik Sintetik, Problem Solving, experiment, demonstrasi, karya wisata, kerja kelompok, proyek, role playing, insersi, team teaching.

Menurut Tim Dosen AP UNY (2011, p.50), "Peserta didik adalah seseorang yang terdaftar dalam suatu jalur, jenjang, dan jenis lembaga pendidikan tertentu, yang selalu ingin mengembangkan potensi dirinya baik pada aspek akademik maupun non akademik melalui proses pembelajaran yang diselenggarakan". Dapat disimpulkan peserta didik adalah komponen masukan dalam proses pendidikan sebagai suatu organisme yang hidup, memiliki potensi untuk berkembang, memerlukan lingkungan dan arah tertentu sehingga membutuhkan bimbingan dan pembelajaran. Dengan kata lain, dari pendapat tersebut dapat disimpulkan bahwa pembelajaran adalah proses untuk membantu peserta didik agar dapat belajar dengan baik.

Menurut Said Hamid Hasan (2009, p.41), “Evaluasi kurikulum sebagai usaha 
sistematis mengumpulkan informasi mengenai suatu kurikulum untuk digunakan sebagai pertimbangan mengenai nilai dan arti dari kurikulum dalam suatu konteks tertentu". Menurut Gronlund (Rusman, 2011, p.93), "Evaluasi kurikulum adalah suatu proses yang sistematis dari pengumpulan, analisis dan interpretasi informasi/data untuk menentukan sejauh mana siswa telah mencapai tujuan pembelajaran". Menurut Oliva (1992, p.448) evaluasi kurikulum dan atau pembelajaran setidaknya terdiri dari evaluasi formatif dan evaluasi sumatif, "Formative evaluation consists of the formal and informal techniques, including, testing, that are used during the period instruction ... summative evaluation is the assesment that takes place at the end of a course or unit". Artinya evaluasi formatif terdiri dari teknik formal dan informal, termasuk, pengujian, yang digunakan selama waktu pengajaran .... evaluasi sumatif adalah penilaian dari yang berlangsung pada akhir kursus atau bagian. Evaluasi kurikulum adalah "Determining the efficacy, value, etc, of a specific curriculum in terms of the validity of objectives, relevancy and sequence of content, and achievement of specified goals" (http://www.education.com/defini tion/curriculum-evaluation diakses pada 07 November 2012, pukul 05.45).

Untuk mencapai tujuan pendidikan, maka S1 Keperawatan STIKES Yogyakarta perlu memantau manajemen pembelajaran yang meliputi: 1) perencanaan, 2). Pelaksanaan, dan 3) evaluasi.

\section{Metode Penelitian}

Jenis penelitian

Penelitian ini menggunakan pendekatan kualitatif. Pendekatan ini digunakan karena tujuan penelitian yang hendak dicapai adalah menggambarkan dan memperoleh pemahaman tentang fakta manajemen kurikulum di S1 Keperawatan STIKES Yogyakarta dengan cara interaktif tatap muka yang memerlukan waktu relatif lama untuk mengamati, mewawancarai, dan merekam sistematis proses-proses yang terjadi secara alami. Jenis penelitian ini merupakan penelitian deskriptif kualitatif, yaitu penelitian yang dituntut untuk menampilkan deskripsi secara kental atau thick description, yaitu memandu peneliti untuk mengeksplorasi dan memotret situasi sosial yang akan diteliti secara menyeluruh, luas dan mendalam

\section{Waktu dan Tempat Penelitian.}

Tempat pelaksanaan penelitian ini adalah S1 Keperawatan STIKES Yogyakarta. Alasan pemilihan tempat ini adalah S1 Keperawatan STIKES Yogyakarta baru berdiri pada tahun 2008 dan dari hasil akreditasi BAN PT adalah C, sehingga dari segi pengelolaan kurikulum belum dilaksanakan secara optimal. Studi pendahuluan dilakukan pada bulan November sampai dengan bulan Desember 2012. Penelitian dilakukan pada bulan Januari sampai dengan bulan Maret 2013.

Target/Subjek Penelitian

Pembantu Ketua I Bidang Akademik Pendidikan dan Pengajaran, sebagai pelaksanaan koordinasi proses belajar mengajar serta penyelenggaraan perkuliahan, sebagai koordinasi pengembangan kurikulum bersama program studi. Pembantu Ketua III Bidang Kemahasiswaan dan Pengabdian Masyarakat, penanggung jawab untuk memimpin pelaksanaan kegiatan pembinaan dan pelayanan kesejahteraan mahasiswa yang merupakan kegiatan di bidang pendidikan yang bersifat kokurikuler. Dosen yang memiliki peran besar dalam peren-canaan, pelaksaan, dan evaluasi dari kurikulum yang diterapkan di S1 Keperawatan STIKES Yogyakarta, dan tenaga kependidikan. Peserta didik sebagai objek dari pelaksanaan kuriku-lum yang diberlakukan di S1 Keperawatan STIKES Yogyakarta.

Teknik dan Instrumen Pengumpulan Data

Wawancara yang dilakukan peneliti di S1 Keperawatan STIKES Yogyakarta dimaksudkan untuk mengumpulkan data, berdialog dengan informan. Wawancara mendalam dilakukan terhadap seluruh unsur responden, yaitu Pembantu Ketua I Bidang Akademik Pendidikan dan Pengajaran, Pembantu Ketua III Bidang Kemahasiswaan dan Pengabdian Masyarakat, dosen, tenaga kependidikan, dan perwakil- 
an dari peserta didik. Siswa yang dijadikan sumber responden pada penelitian ini adalah 2 orang dari semester 4 , dan 1 orang dari semester 6, dipilih secara random. Dalam teknik pengumpulan data, wawancara yang digunakan adalah wawancara terstruktur, dengan menyiapkan instrumen penelitian berupa pertanyaan-pertanyaan tertulis. Selain itu saat pengumpulan data menggunakan alat bantu seperti tape recorder dan kamera.

Observasi dilakukan antara lain untuk mengamati situasi pembelajaran di dalam kelas dan untuk mengamati situasi lingkungan S1 Keperawatan STIKES Yogyakarta. Proses observasi dibantu instrumen pedoman observasi, camera, dan video recorder untuk mendokumentasikan hasil observasi yang telah dilakukan.

Pencermatan dilakukan terhadap dokumen-dokumen yang berkaitan dengan penelitian ini antara lain: visi, misi, kebijakan dan peraturan sekolah, struktur kurikuum, kalender pendidikan, jadwal pelajaraan, sarana-prasarana, jumlah tenaga pendidik dan tenaga kependidikan yang dimiliki. Proses pencermatan dokumen didukung dengan pedoman dokumentasi dan flash disk untuk menyimpan dokumen soft copy yang akan dicermati.

Teknik Keabsahan Data

Teknik pengujian keabsahan data pada penelitian ini mengikuti pendapat Sugiyono (2012, p.270) mengenai uji keabsahan data pada penelitian kualitatif, yaitu meliputi uji: credibility, transferability, dependability, konfirmability.

Teknik Analisis Data

Dalam penelitian ini menggunakan cara yang dipakai oleh Miles dan Huberman yaitu teknik analisis data dilakukan secara interaktif dan berlangsung secara terus menerus sampai tuntas, sehingga datanya sudah jenuh. Masalah reduksi data, penyajian data, dan penarikan kesimpulan merupakan rangkaian kegiatan analisis yang saling susul-menyusul. Dengan demikian analisis yang dimaksud merupakan kegiatan lanjutan dari langkah pengumpulan data. Dalam hal ini kesim- pulan dilakukan secara bertahap, pertama berupa kesimpulan sementara, namun dengan bertambahnya data maka perlu dilakukan verifikasi data yaitu dengan mempelajari kembali data-data yang ada (yang direduksi maupun disajikan). Disamping itu, dilakukan dengan cara meminta pertimbangan dengan pihak-pihak yang berkenaan dengan penelitian ini yaitu kepada pihak Pembantu Ketua I, III, dan dosen. Setelah hal itu dilakukan, maka peneliti baru dapat mengambil keputusan akhir.

\section{Hasil Penelitian}

Perencanaan Pembelajaran

\section{Tujuan Kurikulum}

Berdasarkan hasil wawancara dengan Pembantu Ketua I dan Pembantu Ketua III S1 Keperawatan STIKES Yogyakarta (lampiran 5.d \& 5.e), manajemen kurikulum mengacu pa-da usulan yang ditetapkan oleh AIPNI. Implementasi Kurikulum Berbasis Kompetensi telah diwajibkan oleh Organisasi AIPNI untuk diselenggarakan di Institusi Kesehatan yang menyelenggarakan Pendidikan Sarjana Keperawatan dan Profesi Ners. KBK disusun berdasarkan: a) Undang-Undang Sisdiknas Nomor 20 tahun 2003, tentang Sistem Pendidikan Tinggi Nasional, b) Peraturan Pemerintah No-mor 60 Tahun 1999, tentang Perguruan Tinggi, c) Keputusan Menteri Pendidikan Nasional Republik Indonesia Nomor 232/U/2000 tentang Pedoman Penyusunan Kurikulum Pendidikan Tinggi dan Penilaian Hasil Belajar Mahasiswa, d) Keputusan Menteri Pendidikan Nasional Republik Indonesia dan Penilaian Hasil Belajar Mahasiswa, e) Keputusan Menteri Pendidikan Nasional Republik Indonesia Nomor 045/U/2002 tentang Kurikulum Inti Pendidikan Tinggi, f) Keputusan Direktur Jenderal Pendidikan Tinggi Departemen Pendidikan Nasional Republik Indonesia Nomor 38/ DIKTI/Kep/2002 tentang Rambu-Rambu Pelaksanaan Mata Ku-liah Pengembangan Kepribadian di Perguruan Tinggi, g) Kurikulum Pendidikan Ners dan oleh Asosiasi Institusi Pendidikan Ners Indonesia (AIP- 
NI). Untuk mewujudkan outcomes pendidikan yang akan dituju, disusun Profil Lulusan Keperawatan S1 STIKES Yogyakarta: 1) Care provider: pemberi asuhan keperawatan secara profesional.; 2) Community leader: pemrakarsa (pemimpin) kesehatan di masyarakat.; 3) Educator: pendidikan untuk masyarakat dalam bidang kesehatan.; 4) Researcher: peneliti pemula bidang keperawatan.; 5) Manager: pengelola asuhan keperawatan.

Pengembangan kurikulum pendidikan S1 Keperawatan STIKES Yogyakarta merupakan kurikulum tahap akademik yang terdiri dari kurikulum inti dan kurikulum institusi dan memuat kompetensi utama, pendukung dan lainnya.

Kompetensi yang harus dimiliki oleh Lulusan Keperawatan S1 STIKES Yogyakarta: 1) mampu berkomunikasi secara efektif; 2) mampu menerapkan aspek etik dan legal dalam praktik keperawatan; 3) mampu melaksanakan asuhan keperawatan profesional di klinik dan komunitas; 4) mampu mengaplikasikan kepemimpinan dan manajemen keperawatan; 5) mampu menjalin hubungan interpersonal; 6) mampu melakukan penelitian keperawatan; 7) mampu mengembangkan profesionalisme secara terus-menerus atau belajar se-panjang hayat.

\section{Menentukan Proses Belajar Mengajar}

Berdasarkan wawancara dengan Pembantu Ketua I, kurikulum inti breakdown dari AIPNI, yang di dalamnya memuat Garis-Garis Besar Pokok Pembelajaran (GBPP) dan Satuan Acara Perkuliahan (SAP). GPBB dan SAP merupakan bahan untuk menyusun rancangan pembelajaran yang lebih lengkap dan komunikatif. Rancangan yang lengkap itu, umum disebut sebagai Kontrak Perkuliahan. Dinamakan Kontrak Perkuliahan, karena sebelum dipakai, rancangan tersebut harus telah didiskusikan dan disepakati oleh mahasiswa, sehingga menjadi "kontrak" kerja antara dosen dan mahasiswa.

Struktur kurikulum Program Studi S1 Keperawatan STIKES Yogyakarta yang sudah ditetapkan AIPNI, mata kuliah di- atur berdasarkan sistem, sehingga dalam proses pembelajaran diperlukan team teaching, seperti yang diungkapkan Pembantu Ketua III dan Dosen IDK II. Sekarang istilahnya per sistem, seperti blok. Misalnya sistem respirasi itu berarti belajar tentang pernafasan, mulai dari usia anak sampai orang tua. Mulai dari anatominya seperti apa, psikolog nya seperti apa, sampai ke gangguannya, jadi sudah dikelompokkan per sistem, contoh lain di semester IV belajar sistem pencernaan sampai di semester VIII diberikan mata kuliah sistem kegawatdaruratan.

Pelaksanaan Pembelajaran

Pengelolaan Motivasi Belajar

Kompetensi pedagogis dan profesional adalah kompetensi yang menunjukkan kemampuan dosen dalam mengelola pembelajaran dan kemampuan dosen untuk menguasai content serta metodologi pembelajaran. Berdasarkan wawancara dengan Ketua I masih ada kendala dari dosen karena belum semuanya S2, sehingga pemenuhan tanggung jawab mengajar sesuai dengan bidangnya belum tercapai. Sebagaimana yang diutarakan Dosen Ilmu Gizi dosen yang memenuhi tanggung jawab sebagai pengemban kurikulum adalah dosen yang mengetahui kondisi lapangan, kemudian bisa menerapkan metode pembelajaran dengan memberikan kasus. Untuk memperoleh penguasaan metode ini dosen harus yang sudah berpengalaman bekerja di rumah sakit sebagai perawat. Selain mendapatkan pengalaman selama menjadi perawat, untuk memenuhi kompetensi profesional, mengambil S2 Pendidikan Profesi Keperawatan.

\section{Pengelolaan Bahan Ajar}

Berdasarkan wawancara dengan Koordinator Perpustakaan (lampiran 5.g), koleksi buku yang ada di perpustakaan STIKES Yogyakarta setiap tahun diperoleh dari Yayasan, kemudian pada tahun 2011 dan 2012 mendapat dana hibah buku dari DIKTI. Untuk menciptakan koleksi perpustakaan yang sesuai dengan kebutuhan mahasiswa, koordinator perpustakaan mencatat semua usulan buku dari dosen. Karena sumber buku mengacu kepada 
usulan AIPNI, maka mahasiswa terbantu untuk memanfaatkan perpustakaan dengan banyak baca dan pinjam buku.

Pengelolaan Strategi Pembelajaran

Metode pembelajaran yang digunakan selama proses pembelajaran di S1 Keperawatan STIKES Yogyakarta mengacu kepada buku panduan AIPNI, seperti yang dijelaskan oleh Dosen IDK II, dan Dosen Sistem Neurobehavior dalam wawancara di bawah ini.

Dalam buku panduan AIPNI sudah lengkap tertulis mulai dari GBPP, jumlah SKS yang harus diambil, mata kuliah wajib apa saya yang harus diambil, semuanya sudah ada di panduan AIPNI.

Berdasarkan hasil wawancara dengan Pembantu Ketua III, karena kuliahnya berdasarkan sistem, maka metode pembelajaran yang tepat menggunakan team teaching, misalnya dalam sistem sensori persepsi, mempelajari sistem sensori mulai dari bayi, anak-anak, dewasa, dan lansia. Untuk memenuhi kompetensi ini, diperlukan team teaching dosen spesialisasi anak dan lansia.

\section{Pengelolaan Media Pembelajaran}

Berdasarkan hasil wawancara dengan bagian rumah tangga, media pembelajaran yang ada di kelas di up date setiap akhir tahun, sampai saat ini ruangan masingmasing kelas di STIKES Yogyakarta telah diiventarisasi untuk media pembelajaran terdiri dari LCD proyektor, speaker, papan tulis, komputer, mic, ampli. Dengan fasilitas ini, berdasarkan hasil wawancara dengan mahasiswa media pembelajaran yang ada di STIKES Yogyakarta cukup lengkap, sehingga mendorong mereka lebih aktif dalam belajar. Namun media pembelajaran yang ada berhubungan dengan praktik masih belum lengkap, sesuai dengan hasil wawancara dengan koordinator laboratorium, laboratorium yang ada di STIKES Yogyakarta adalah lab terpadu, artinya kebidanan dan keperawatan menjadi satu, sehingga ruangan terbagi dalam sekat-sekat yang sempit. Laboratorium ini terbagi dalam ruang medikal bedah, mikro biologi, UGD, ICU, ruang inap jiwa, dan ruang anak. Dari kondisi ruangan yang masih sempit ini penciptaan mini hospital belum terwujud.

\section{Pengelolaan Peserta Didik}

Dalam kegiatan pengabdian kepada masyarakat, berdasarkan wawancara dengan Pembantu Ketua III di bawah ini, diagendakan satu bulan satu kali dimana pesertanya adalah mahasiswa semester 5 karena dinilai sudah cukup layak terjun ke masyarakat. Kemarin agendanya perbulan $\mathrm{Bu}, 1$ bulan 1 tempat. Jadi ada masyarakat yang meminta pelayanan dari kita dan ada juga yang memang kita merasa masyarakat butuh, kayak yang kemarin di Sleman Barat karena jauh dari jangkauan, maka kita datang ke daerah itu. Untuk daerah tersebut sasarannya menjadi desa binaan, jadi untuk praktek anak-anak komunitas juga di sana, supaya berkesinambungan. Selain hasil wawancara dengan Pembantu Ketua III, hasil wawancara diperoleh dari Dosen Ilmu Gizi, walaupun terbentur dana diusahakan ada kegiatan pengobatan masal yang diadakan sedikitnya 3 bukan 1 kali. Pada acara DIES NATALIS STIKES Yogyakarta telah diadakan pengobatan masal.

Bimbingan dan konseling merupakan alat bantu bagi mahasiswa dalam menyusun dan merencanakan program perkuliahan agar cukup efektif. Melalui kegiatan bimbingan dan konseling diharapkan produktivitas program studi dapat ditingkatkan. Kenyataan yang ada di S1 Keperawatan STIKES Yogyakarta belum tercapai, sesuai hasil wawancara dengan Dosen IDK II, Dosen Sistem Perkemihan, menjelaskan bahwa bimbingan hanya berjalan saat akan bimbingan pengisian KRS, dan berdasarkan hasil wawancara dengan mahasiswa (lampiran 5.i), mereka menginginkan ada bimbingan saat menghadapi kesulitan tentang praktikum atau kurikulum, namun mahasiswa cenderung takut menanyakan itu.

\section{Pengelolaan Kelas}

Kegiatan rutin dosen yang dilakukan secara organisasional akan dapat mencegah masalah pengelolaan kelas. Namun kenyataan yang ada di S1 Keperawatan 
STIKES Yogyakarta, dosen yang berhalangan hadir masih sering terjadi, baik dari dosen luar maupun dosen dalam. Hal ini diutarakan oleh koordinator akademik, untuk dosen luar yang jam terbangnya tinggi, pada saat tidak bisa masuk, sulit untuk mencari hari penggantinya, dikarenakan bentrok dengan mata kuliah lain. Selain itu menurut Staf Laboratorium Klinik, menjelas-kan bahwa praktik di laboratorium yang terpadu kendalanya ada di jadwal, sering dosen dalam tidak hadir padahal sudah disiapkan alat dan ruangan. Begitu pun dari hasil wawancara dengan mahasiswa, dosen dalam lebih sering melakukan perubahan jadwal kuliah daripada dosen luar.

Program praktik klinik dilakukan di rumah sakit, sebelum kegiatan praktik klinik mahasiswa diwajibkan mengikuti ujian praktik skill dan osca. Namun masih ada kendala saat praktik klinik di rumah sakit. Berdasarkan hasil wawancara dengan mahasiswa, komunikasi antara dosen dan mahasiswa belum komunikatif, hal ini disebabkan adanya keterbatasan waktu yang diberikan oleh dosen pembimbing praktik.

Evaluasi Pembelajaran

\section{Evaluasi Struktur Kurikulum}

Berdasarkan hasil wawancara dengan Pembantu Ketua III, ada pengembangan sedikit dari kurikulum 2009 ke kurikulum 2010. Hasil evaluasi kurikulum AIPNI, dinilai oleh ahli kurikulum dari DIKTI ada mata kuliah yang jumlah SKSnya terlalu besar untuk mahasiswa semester awal padahal kalau dilihat dari isi pelajarannya sulit, sehingga memberatkan mahasiswa. Selain itu untuk pengkodean mata kuliah IKD I dan IKD II, menurut pengamatan ahli kurikulum pengkodean 1 dan 2 menggambarkan prerequisite, padahal mata kuliah tersebut tidak berhubungan.

\section{Evaluasi Pembelajaran}

Berdasarkan penjelasan koordinator akademik, untuk evaluasi dosen, dilakukan saat ujian akhir, namun hanya diambil secara sampling saja, seperti yang beliau jelaskan. Iya semua dosen, misalnya dalam satu mata kuliah ada 3 dosen yang mengampu, nanti satu kelas-nya dibagi 3 dosen tersebut, misalnya dalam satu kelas ada 20 mahasiswa, jumlah tersebut dibagi 3 untuk 3 dosen, tidak semuanya karena kebanyakan, jadi diambil samplingnya saja. Kan cukup untuk mewakili saja. Kebijakan dari bagian akademik ini menimbulkan ketidakpuasan dari mahasiswa, seperti yang diungkapkan mahasiswa semester 6 dan 8 berikut ini. Idealnya sih kita diberi kesempatan untuk mengisi angket, namun seringnya banyak alas-an yang akhirnya kita tidak mengisi angket, misalnya copyannya habislah, kan bisa diperbanyak, padahal itu penting.

\section{Pembahasan}

Perencanaan Pembelajaran S1

Keperawatan STIKES Yogyakarta

Tujuan penyelengaraan pendidikan Program Studi S1 Keperawatan STIKES Yogyakarta disesuikan dengan visi dan misi Program Studi. Untuk mencapai tujuan Program Studi ditetapkan profil lulusan yang mengacu kepada panduan AIPNI. Profil yang diharapkan setelah menjalani proses pembelajaran di S1 Keperawatan STIKES Yogyakarta adalah care provider, community leader, educator, researcher, dan manager. Sementara tujuan kurikulum dan bentuk kompetensi mengacu kepada panduan yang dikeluarkan AIPNI. Un-tuk mewujudkan tujuan kurikukum tersebut, disusun kompetensi utama, pendukung dan lainnya. Sebagai dasar untuk menjamin agar kualitas lulusan dapat berkompetensi secara global, penyusunan kompetensi utama lulusan mengikuti acuan dari AIPNI. Kompetensi yang akan dicapai memerlukan bahan kajian yang membahas pengetahuan dan keterampilan terkait yang sesuai. Pada pedoman AIPNI digambarkan bahan kajian berdasarkan unit kompetensi yang merupakan jabaran dari kompetensi utama lulusan sarjana keperawatan. Setelah kompetensi lulusan terumuskan, langkah selanjutnya adalah mengkaji apakah kompetensi tersebut mengandung kelima elemen kompetensi seperti yang diwajibkan dalam Kepmendiknas Nomor 045/U/2002. Kelima elemen 
kompetensi tersebut adalah: a) landasan kepribadian, b) penguasaan ilmu dan keterampilan, c) kemampuan berkarya, d) sikap dan perilaku dalam berkarya menurut tingkat keahlian berdasarkan ilmu dan keterampilan yang dikuasai, dan e) pemahaman kaidah berkehidupan bermasyarakat sesuai dengan pilihan keahlian dalam berkarya. Di S1 Keperawatan STIKES Yogyakarta belum ada matriks penghubung antara rumusan kompetensi dan elemen kompetensi. Dengan melihat kurikulum panduan AIPNI, setelah merumuskan kompetensi, ditentukan bahan kajian yang akan dipelajari. Struktur kurikulum S1 Keperawatan STIKES Yogyakarta terdiri dari kurikulum 2009 dan 2010. Untuk semester 5 menggunakan kurikulum 2010 dan semester 7 menggunakan kurikulum 2009. Struktur kurikulum mengacu kepada pedoman AIPNI dan DIKTI. Dikarenakan adanya dua acuan tersebut, masih ada kendala di lapangan, misalnya dalam penentuan beban SKS dan penamaan mata kuliah. Total bebas SKS adalah 148 SKS terdiri dari kurikulum inti/nasional dan kurikulum lokal/institusi. Struktur kurikulum berdasarkan kelompok bahan kajian tidak disajikan ke dalam lima unsur kompetensi mata kuliah, sehingga jumlah SKS lokal tidak diketahui.

Rencana pembelajaran S1 Keperawatan STIKES Yogyakarta sudah tertuang dalam buku pedoman akademik. Pada halaman 141 Garis-garis Besar Pokok Pembelajaran (GBPP) terdiri dari standar kompetensi, deskripsi mata kuliah, tujuan, proses pembelajaran, evaluasi, dan buku sumber. SKS terdiri dari teori, laboratorium, dan klinik. Kalender akademik dilakukan dengan menyesuaikan alokasi waktu yang telah ditetapkan sebelumnya sehingga kalender akademik yang digunakan dibuat setelah menentukan alokasi waktu tiap semester. Mekanisme penyusunan jadwal ditentukan oleh PJMK, membuat team teaching sesuai dengan tuntutan mata kuliah berdasarkan sistem. Proses pembelajaran mengacu kepada panduan yang ditetapkan oleh AIPNI, namun dalam rencana pembelajaran belum mengacu ke real problem solution. Dalam proses rancangan pembelajaran adalah memilih metode pembelajaran yang tepat agar mencapai kompetensi yang diterapkan. Aspek penting yang harus diperhatikan adalah pertama mengukur tingkat kesulitan atau kompleksitas bahan kajian terhadap tingkat kemampuan mahasiswa yang akan belajar. Kedua adalah kaitan antara mahasiswa dengan sarana pembelajaran, perlu diperhatikan tingkat efisiensinya. Ketiga ada-lah kaitan antara tingkat kesulitan dan macam bahan kajian dengan sarana pembelajaran yang dipilih.

Pelaksanaan Pembelajaran S1 Keperawatan STIKES Yogyakarta

Kegiatan pembelajaran diselenggarakan untuk membentuk watak, peradaban, dan meningkatkan mutu kehidupan peserta didik. Kegiatan pembelajaran memberdayakan semua potensi peserta didik untuk menguasai kompetensi yang diharapkan. Pemberdayaan diarahkan untuk mendorong pencapaian kompetensi dan perilaku khusus supaya setiap individu mampu menjadi pembelajar sepanjang hayat dan mewujudkan masyarakat belajar. Dalam kurikulum berbasis kompetensi yang memiliki karakteristik yaitu: a) menekankan pada ketercapaian kompetensi siswa baik secara individual maupun klasikal, b) berorientasi pada hasil belajar (learning outcomes) dan keberagaman, c) penyampaian dalam pembelajaran menggunakan pendekatan dan metode yang bervariasi, d. sumber belajar bukan hanya guru, tetapi juga pada sumber belajar lainnya yang memenuhi unsur edukatif, e. penilaian menekankan pada proses dan hasil belajar dalam upaya penguasaan atau pencapaian suatu kompetensi. Untuk memenuhi tuntutan tersebut dosen sebagai salah satu unsur dinamis dalam memotivasi belajarkan siswa, diperlukan berbagai kemampuan mengajar.

Keterampilan soft skills merupakan bagian dari kompetensi kepribadian yang sudah ditetapkan undang-undang menjadi salah satu kompetensi yang harus dimiliki dosen. Keterampilan soft yang diperlukan 
dalam pekerjaan dosen antara lain berupa keterampilan soft yang berhubungan dengan karakteristik kepribadian yaitu: dapat menghormati orang lain, memiliki motivasi kerja yang tinggi, disiplin, percaya diri, pengendalian diri, self esteem, rasa tanggung jawab, mampu memutus stres, mengambil keputusan yang efektif, melatih inisiatif, dan mudah beradaptasi dengan lingkungan budaya yang berlainan keterampilan. Dengan keterampilan inilah, dosen harus dapat memberikan rasa nyaman pada mahasiswa karena merasa dihargai dan tidak takut salah saat mencoba serta menciptakan suasana belajar yang kondusif dan tidak membosankan sehingga potensi mahasiswa dapat dikembangkan secara optimal. Dosen di S1 Keperawatan STIKES Yogyakarta masih ada yang mengajar berdasarkan mood, masih ada dosen yang saat menjelaskan tidak menguasai materi, masih ada dosen pembimbing yang belum respek terhadap mahasiswa dan kurang pengontrolan diri. Dari keadaan ini memberikan gambaran bahwa dosen belum bisa memberikan motivasi untuk membelajarkan mahasiswa, sedangkan motivasi itu sebaiknya timbul dari kesadaran yang tinggi dari dosen sehingga menjadi teladan bagi peserta didiknya. Untuk menjadi dosen teladan bagi peserta didiknya, ada beberapa hal yang perlu diperhatikan yaitu: a. naluri untuk memotivasi mahasiswa ke arah kemajuan melalui perilaku dan sikap keteladanan dosen, b. minat, yaitu sikap yang mengarahkan kecenderungan dam perhatian pada suatu keadaan, c. niat, yaitu sikap untuk mengarahkan potensi dan kehendak untuk bertindak dan berupaya, d. kiat, yaitu kemampuan untuk menggunakan perilaku (pengetahuan, keterampilan dan sikap), dalam tindakan untuk mencapai tujuan.

Kompetensi profesional dosen dapat dilihat dari beberapa indikator yaitu penguasaan bahan, pengelolaan program belajar mengajar, pengelolaan kelas, penggunaan media dan sumber belajar.

Kualitas institusi pendidikan sangat dipengaruhi oleh masukan bagi fasilitas sarana pendukung proses belajar mengajar. Pada perpustakaan perguruan tinggi sebaiknya pengadaan koleksi yang tepat adalah memilih koleksi perpustakaan yang mengikuti arah perkembangan ilmu pengetahuan dan teknologi, sehingga pengguna di perpustakaan ini mendapatkan informasi-informasi yang sesuai dengan perkembangan zaman di bidang pendidikan dan pengetahuan umum. Dengan demikian koleksi yang disediakan di perpustakaan sesuai dengan kebutuhan dan bermanfaat bagi penggunanya. Perpustakaan S1 Keperawatan STIKES Yogyakarta dalam pengadaan buku, bersumber dari AIPNI. Ketua Program Studi memberikan masukan ke bagian perpustakaan buku apa saja yang menjadi sumber pembelajaran, sehingga bahan pustaka dapat menyediakan informasi yang cocok dengan kebutuhan mahasiswa.

Pendidik agar berhasil dalam melaksanakan proses belajar mengajar maka harus memiliki kemampuan dasar, salah satu diantaranya adalah disiplin menjalankan tugas. Dosen di S1 Keperawatan STIKES Yogyakarta baik dosen dalam maupun dosen luar, dalam menjalankan kewajiban mengajar masih ada yang sering mengubah jam mata kuliah, dan berhalangan hadir. Dengan kondisi ini menyebabkan jumlah jam dan materi tidak terpenuhi.

Pembelajaran menurut UndangUndang Sisdiknas Nomor 2 Tahun 2003 dinyatakan bahwa yang dimaksud dengan pembelajaran adalah interaksi antara pendidik, peserta didik, dan sumber belajar di dalam lingkungan belajar tertentu. Sehingga dengan mendeskripsikan setiap unsur yang terlibat dalam pembelajaran tersebut, S1 Keperawatan STIKES Yogyakarta menggunakan pembelajaran modifikasi Teacher Centered Learning dan Student Centered Learning. Dalam proses pembelajaran dosen menerapkan berbagai metode pembelajaran dari modifikasi SGD, contextual instruction, presentasi kelompok, dan lecture. Melihat kecepatan belajar peserta didik di S1 Keperawatan STIKES Yogyakarta berbeda maka sebaiknya perlu ada 
pemilihan metode pembelajaran yang tepat sesuai dengan kemampuan peserta didik.

Dalam melaksanakan proses pembelajaran diperlukan media pembelajaran supaya hasil pembelajaran dapat optimal. Media pembelajaran yang ada di S1 Keperawatan STIKES Yogyakarta cukup memuaskan mahasiswa, dimana manfaat dari tersedianya media pembelajaran tujuan belajar akan lebih mudah tercapai secara maksimal dengan waktu dan tenaga seminimal mungkin. Dosen tidak harus menjelaskan materi ajaran secara berulangulang, sebab dengan sekali sajian menggunakan media, peserta didik akan lebih mudah memahami pelajaran. Namun laboratorium sebagai media pembelajaran untuk praktik, masih terpadu dengan kebidanan. Ruangan yang terdiri dari gawat darurat, mikro biologi, maternitas, rawat dasar, rawat inap masih tersekatsekat, sehingga luas ruangan tidak sesuai dengan jumlah mahasiswa.

Pembinaan peserta didik adalah salah satu kegiatan dari pengelolaan peserta didik. Pembinaan peserta didik dapat berupa bimbingan dan konseling, dan program kreativitas mahasiswa. Bimbingan dan konseling merupakan alat bantu bagi mahasiswa dalam menyusun dan merencanakan program perkuliahan agar cukup efektif. Kegiatan bimbingan dan konseling merupakan dua kegiatan yang saling berkaitan dan bertujuan untuk membantu mahasiswa mengembangkan kemampuannya dalam proses penyelesaian studinya. Kegiatan ini dilakukan oleh staf pengajar atau pejabat lain yang memiliki tugas, fungsi dan tangung jawab dalam bidang pengembangan kemahasiswaan di perguruan tinggi karena tugas atau jabatan. Bimbingan dan konseling dalam keseluruhan proses pendidikan di perguruan tinggi bertujuan agar mahasiswa mencapai perkembangan yang optimal secara akademis, psikologis, dan sosial. Secara akademis, hasil bimbingan dan konseling dicerminkan oleh kecepatan mahasiswa mencapai penyesuaian akademis dan prestasi belajar yang memadai. Secara psikologis, pelayanan bimbingan dan konseling meng- hasilkan perkembangan dan kematangan pribadi. Secara sosial, berupa pencapaian penyesuaian dan memiliki keterampilan sosial yang memadai. Bimbingan dan konseling di S1 Keperawatan STIKES Yogyakarta belum berjalan lancar, bimbingan dan konseling masih terpaku pada saat pengisian KRS. Mahasiswa cenderung takut melakukan bimbingan karena sikap dosen yang tidak terbuka. Kegiatan pengabdian kepada masyarakat dilaksanakan dengan melibatkan mahasiswa mulai dari semester 5 yang dianggap sudah mampu terjun ke lapangan.

Organisasi Kemahasiswaan Intra Universitas yang berfungsi sebagai wahana dan sarana pengembangan diri mahasiswa ke arah perluasan wawasan, peningkatan kecendekiaan, dan integritas kepribadian mahasiswa menuju terciptanya tujuan pendidikan nasional yang berkualitas. Dengan demikian, Organisasi Kemahasiwaan Intra Universitas bertugas melaksanakan kegiatan kemahasiswaan yang bersifat ekstrakurikuler meliputi kepemimpinan, penalaran, minat dan bakat, serta kesejahteraan mahasiswa. S1 Keperawatan STIKES Yogyakarta memiliki organisasi kemahasiswaan yang menyelenggarakan kegiatan ektrakurikuler diutamakan untuk mahasiswa angkatan baru, dan bagi mahasiswa semester 5 wajib mengikuti kegiatan pengabdian kepada masyarakat. Kegiatan ekstrakurikuler disesuaikan dengan minat dan bakat mahasiswa. Kegiatan pengabdian kepada masyarakat diagendakan 1 bulan 1 kali, berdasarkan permintaan pelayanan dan ada juga yang dinilai bahwa masyarakat butuh pelayanan. Untuk yang lokasinya jauh, biasanya dijadikan sasaran desa binaan, sehingga kegiatan ini berkelanjutan.

Individu dan lingkungan terjalin proses interaksi atau saling memengaruhi satu dengan yang lainnya. Tingkah laku individu dapat menyebabkan perubahan pada lingkungan bentuk positif dan negatif. Pendayagunaan lingkungan dalam proses pembelajaran dapat dilaksanakan dengan cara membawa lingkungan ke dalam kelas. Pembelajaran di kelas erat 
kaitannya dengan pengelolaan kelas yang berhubungan dengan disiplin waktu. Mematuhi aturan waktu yang telah dijadwalkan akan menciptakan pembelajaran yang efektif. Namun dalam pengelolaan kelas yang berhubungan dengan disiplin waktu, baik dosen dalam maupun dosen luar di S1 Keperawatan STIKES Yogyakarta masih banyak yang mengganti jadwal bahkan tidak hadir, sehingga bagian akademik sulit mencari hari penggantinya karena sering tabrakan dengan jadwal mata kuliah lainnya.

Evaluasi Pembelajaran S1 Keperawatan STIKES Yogyakarta

Dalam setiap program studi ada rumusan misi dan tujuan pendidikan yang salah satu jabarannya merupakan kualifikasi lulusan (kompetensi) yang akan dihasilkan. Rumusan kompetensi lulusan merupakan rumusan outcomes yaitu suatu bentuk kemampuan yang kelak akan ditunjukkan atau dibuktikan di lapangan pekerjaan yang dipilihnya. Orientasi terhadap pemenuhan kebutuhan didasarkan penghayatan hasil pendalaman terhadap sinyal pasar (market signal) dan visi ilmu pengetahuan (science vision). Menetapkan tujuan dalam bentuk kompetensi program studi bukanlah sembarangan, bukan pula copy-paste dari tempat lain, namun ditemukan berdasarkan visi dan misi yang dimiliki tiap program studi. Panitia kurikukum harus melihat referensi secara luas, namun tidak melakukan adopsi sembarangan secara membuta, harus dilakukan kombinasi dengan kemajuan mutakhir dengan konteks lokal, konteks bangsa dan budayanya. Evaluasi tujuan kurikukum S1 Keperawatan STIKES Yogyakarta belum bisa dilakukan, dengan alasan idealnya peninjauan kurikulum dilakukan dengan meluluskan mahasiswanya terlebih dulu. Struktur Kurikulum yang ada di program studi ini terdapat dua kurikulum yaitu kurikulum 2009 dan 2010. Dari kurikulum 2009 ke kurikulum 2010 ada pengembangan sedikit. Hasil evaluasi dari DIKTI ada mata kuliah yang jumlah SKS dan tingkat kesulitannya tidak seimbang. Dalam mata kuliah IKD ada penomoran 1 dan 2, yang dianggap sebagai mata kuliah prerequiste (prasyarat), namun dalam kenyataannya dalam mata kuliah tersebut tidak saling berhubungan. Selain itu dengan adanya dua kurikulum menyebabkan pembengkakan dalam masalah pendanaan.

Hasil evaluasi dosen berkaitan erat dengan unsur dinamis pembelajaran dimana dosen harus memiliki motivasi untuk membuat mahasiswa belajar dan kondisi siap membuat mahasiswa belajar, hal tersebut membutuhkan kemampuan kepribadian dan kemampuan kemasyarakatan. Namun pada kenyataannya, evaluasi dosen di S1 Keperawatan STIKES Yogyakarta tidak efektif karena evaluasi dosen sekedar menjadi kegiatan administratif. Pengisian kuisioner hanya dilakukan oleh sebagian mahasiswa tidak melibatkan seluruh mahasiswa.

\section{Simpulan dan Saran}

Simpulan

Perencanaan kurikulum S1 Keperawatan Yogyakarta yaitu: 1) Menetapkan tujuan program studi dengan merumuskan penyusunan profil lulusan, kompetensi lulusan berdasarkan visi dan misi program studi. Profil lulusan dan kompetensi lulusan diadopsi dari panduan AIPNI. Rumusan kompetensi pendukung dan lainnya tidak terjabarkan dalam elemen kompetensi.; 2) Mata kuliah berdasarkan sistem, sehingga dalam proses pembelajaran memerlukan team teaching. Mekanisme penyusunan jadwal kuliah ditentukan oleh Penanggung Jawab Mata Kuliah dengan melibatkan dosen dalam dan luar.

Pelaksanaan pembelajaran S1 Keperawatan STIKES Yogyakarta meliputi: 1) Dalam membina motivasi belajar mahasiswa yang dilakukan oleh dosen, masih ada dosen yang mengajar berdasarkan mood, kurang respek terhadap mahasiswa dan kurang pengontrolan diri.; 2) Buku yang tersedia di perpustakaan disesuaikan dengan kebutuhan mahasiswa, mengacu kepada usulan AIPNI sehingga mahasiswa bisa memanfaatkan dengan baik. 3) Dalam proses pembelajaran dosen menerapkan 
berbagai metode pembelajaran dari modifikasi SGD, contextual instruction, presentasi kelompok dan lecture dengan tujuan menciptakan kemampuan belajar secara mandiri dan berkelanjutan. 4) Media pembelajaran yang tersedia di kelas cukup memuaskan mahasiswa, karena mahasiswa lebih mudah memahami pelajaran, sehingga tujuan belajar lebih mudah tercapai. Namun laboratorium karena masih terpadu, dimana pemakaiannya masih bersamaan dengan prodi kebidanan, sehingga luas laboratorium tidak seimbang dengan jumlah mahasiswa.; 5) Bimbingan dan konseling mahasiswa masih terbatas saat pengisian KRS. Mahasiswa dilibatkan dalam kegiatan pengabdian kepada masyarakat, diutamakan untuk mahasiswa angkatan baru mengikuti kegiatan ektrakurikuler dalam organisasi kemahasiswaan.; 6) Pengelolaan kelas yang berkenaan dengan disiplin waktu menunjukkan masih sering dari dosen dalam dan luar yang mengganti jadwal bahkan tidak hadir.

Evaluasi pembelajaran S1 Keperawatan STIKES Yogyakarta yaitu: 1) Penamaan mata kuliah IKD dengan penomoran 1 dan 2 berdasarkan ahli kurikulum menunjukkan arti prerequisite, namun dalam kenyataannya mata kuliah tersebut tidak saling berhubungan.; 2) Evaluasi dosen baru sebatas pelaksanaan kegiatan administratif, yang ditandai dengan pengisian kuisioner hanya dilakukan oleh sebagian mahasiswa.

Saran

Penyusunan kompetensi perlu disusun oleh program studi bersama pihakpihak berkepentingan terhadap lulusan (hasil didik), dan kompetensi ditetapkan dengan orientasi pada kebutuhan atau tuntutan kemampuan berkarya di masyarakat.

Mendorong dosen-dosen, khususnya dosen-dosen baru mengikuti pelatihan keterampilan dan "student centered learning".

Kapan pun jika memungkinkan, setiap dosen harus memiliki mata kuliah atau keahlian khusus. Hal ini berhubungan de- ngan temuan dari penelitian bahwa mahasiswa mengharapkan dosen-dosen mereka memiliki pengetahuan yang baik dan ahli dalam bidang yang spesifik.

\section{Daftar Pustaka}

Ahmad Rohani HM. (2010). Pengelolaan pengajaran: sebuah pengantar menuju guru profesional. Jakarta: Rineka Cipta.

Alben Ambarita. (2006). Manajemen pembelajaran. Jakarta: Depdikbud Dikti.

Bharvad, A.J. (September 2010). Curriculum evaluation. Research Paper-Education. Diakses pada tanggal 16 Mei 2013, dari http//www.ssmrae. com/ .../1c8882d306181f62401a4ff1

Daft, R.L. (1991). Management (2nd ed). USA: Dryden Press.

Husaini Usman. (2011). Manajemen: teori, praktik, dan riset pendidikan (ed.3). Jakarta: Bumi Aksara.

Nana Sudjana. (2011). Dasar-dasar proses belajar mengajar. Bandung: Sinar Baru Algesindo.

Oemar Hamalik. (2012). Kurikulum dan pembelajaran. Jakarta: Bumi Aksara.

Oliva, P.F. (1992). Developing the curriculum (3rd ed). USA: Harper Collins Publisher.

Öztürk, I.H. (2011). Curriculum reform and teacher autonomy in turkey: the case of the history teaching. International Journal of Instruction, 116, 1308-1470.

Rusman. (2011). Manajemen kurikulum. Jakarta: Rajagrafindo Persada.

Said Hamid Hasan. (2009). Evaluasi kurikulum. Bandung: Remaja Rosdakarya.

Tim Dosen Administrasi Pendidikan Universitas Pendidikan Indonesia. (2011). Manajemen pendidikan. Bandung: Alfabeta.

Tim Dosen AP. (2011). Manajemen pendidikan. Program Studi Manajemen Pendidikan Jurusan Administrasi Pendidikan Fakultas Ilmu Pendidikan Universitas Negeri Yogyakarta.

Veithzal Rivai \& Sylviana Murni. (2012). Education management analisis teori dan praktik. Jakarta: Raja Grafindo Persada. 